\title{
Abrasive-free Ultrasonic Finishing of Metals
}

Miroslav Müller ${ }^{1}$, Lebedev Anatolii ${ }^{2}$, Svobodová Jaroslava $^{3}$, Náprsková Nataša ${ }^{3}$, Lebedev Pavel $^{4}$

${ }^{1}$ Faculty of Engineering, Czech University of Life Sciences Prague. Czech Republic. E-mail: muller@tf.czu.cz.

${ }^{2}$ Standardization and Metrology, Stavropol State Agrarian Mechanization, Russia. E-mail: lebedev.1962@mail.ru.

${ }^{3}$ Faculty of production technology and management, Jan Evangelista Purkyně University in Ústí nad Labem. Czech Republic. E-mail: svobodova@fvtm.ujep.cz.

${ }^{4}$ Standardization and Metrology, Stavropol State Agrarian Mechanization, Russia. E-mail: zoya-lebedeva@mail.ru.

The aim of the research was to compare a classical (turning) machining and an abrasive-free ultrasonic machining (bufo) at three different materials. The surface was evaluated on the basis of an Olympus LEXT 3100 measuring of a surface roughness and hardness HV5. An ultrasonic set I - 4 consisted of the ultrasonic generator, power output $630 \mathrm{~W}$ and working frequency $22 \mathrm{kHz} \pm 10 \%$, was used for the research. Main results are: increasing of the hardness HV5 of the machined surface, lowering of the roughness parameters Ra at the application of the abrasive-free ultrasonic machining, lowering of the roughness parameters $\mathrm{Rz}$ was not statistically proved at the application of the abrasive-free ultrasonic machining. It is possible to say according to a visual observing of the steel sample surface that a corrosive resistance was increased at the application of the abrasive-free ultrasonic machining.

Keywords: Hardness, Machining, Microscopy, Surface Roughness, Testing

\section{Acknowledgement}

This paper has been done when solving the grant IGA TF (No.: 2014:31140/1312/3133).

\section{References}

[1] NOVÁK, M. (2012). Surfaces with high precision of roughness after grinding. In: Manufacturing technology, Vol. 12, pp. $66-70$.

[2] NOVÁK, M. (2011). Surface quality of hardened steels after grinding. In: Manufacturing technology, Vol. 11, pp.55-59.

[3] HOLEŠOVSKÝ, F., NÁPRSTKOVÁ, N., NOVÁK, M. (2012). GICS for grinding process optimization. In: Manufacturing technology, Vol. 12, pp. 22-26.

[4] PA, P., S. (2009). Super finishing with ultrasonic and magnetic assistance in electrochemical micro-machining. In: Electrochimica Acta, Vol. 54 , pp. 6022-6027.

[5] KROLCZYK, G., LEGUTKO, S. (2013). The machinability of duplex stainless steel-solutions in practice. In: Manufacturing technology, Vol. 13, pp. 473-478.

[6] HOLEŠOVSKÝ, F., NOVÁK, M., LATTER, M., VYSLOUZIL, T. (2013). Machining and its influence to surface quality of machine parts. In: Key Engineering Materials. Vol. 581. pp. 354-359.

[7] JÓZWIK, J., KURIC, I., SÁGA, M., LONKOWIC, P. (2014). Diagnostics of CNC machine tools in manufacturing process with laser interferometer technology. In: Manufacturing technology, Vol. 14, pp. 23-30.

[8] NOVÁK, M. (2013). New ways at the fine grinding. In: Key Engineering Materials. Vol. 581. pp. 255-260.

[9] KOMARAIAH, M., REDDY, N. (1993). A study on the influence of workpiece properties in ultrasonic machining, In: International Journal of Machine Tools \& Manufacture. Vol. 33, pp. 495-505.

[10] CURODEAU, A., GUAY, J., RODRIGUE, D., BRAULT, L., GAGNE, D., BEAUDIOIN, L., P. (2008). Ultrasonic abrasive $\mu$-machining with thermoplastic tooling. In: International Journal of Machine Tools \& Manufacture. Vol. 48, pp. 1553-1561.

[11] LEGUTKO, S., KROLCZYK, G., KROLCZYK, G. (2014). Quality evaluation of surface layer in highly accurate manufacturing. In: Manufacturing technology, Vol. 14, pp. 50-56. 